Dimethyl fumarate treatment in multiple sclerosis: Recent advances in clinical and immunological studies.

Peer-reviewed author version

Hupperts, Raymond; FRAUSSEN, Judith; MONTES DIAZ, Gwendoline \& SOMERS, Veerle (2018) Dimethyl fumarate treatment in multiple sclerosis: Recent advances in clinical and immunological studies.. In: Autoimmunity reviews, 17(12), p. 1240-1250.

DOI: 10.1016/j.autrev.2018.07.001

Handle: http://hdl.handle.net/1942/28195 


\title{
Dimethyl fumarate treatment in multiple sclerosis: recent advances in clinical and immunological studies
}

\section{Gwendoline Montes Diaz ${ }^{1}$, Raymond Hupperts ${ }^{2,3}$, Judith Fraussen ${ }^{1 *}$, Veerle Somers ${ }^{1 *}$}

\author{
${ }^{1}$ Hasselt University, Biomedical Research Institute and Transnationale Universiteit Limburg, School of \\ Life Sciences, Hasselt, Belgium \\ ${ }^{2}$ Department of Neuroscience, School of Mental Health and Neuroscience, Maastricht University, \\ Maastricht, The Netherlands \\ ${ }^{3}$ Department of Neurology, Academic MS Center Limburg, Zuyderland Medisch Centrum, Sittard, The \\ Netherlands
}

* Equal contributing authors: JF and VS contributed equally as senior authors

\section{Correspondence}

Veerle Somers (veerle.somers@uhasselt.be)

Biomedical Research Institute - Hasselt University

Martelarenlaan 42

3500 Hasselt

Belgium

Tel: +32(0)11269202 | Fax +32(0)11269299 


\begin{abstract}
Multiple sclerosis (MS) is a chronic inflammatory autoimmune disease of the central nervous system (CNS) in which demyelination and neurodegeneration occurs. The immune system of MS patients is characterized by a dysregulation in the balance between pro- and anti-inflammatory immune cells, whereby both the innate and adaptive immune system are involved. Dimethyl fumarate (DMF) was licensed in 2013 as an oral first-line therapy for relapsing-remitting (RR)MS patients. It has a strong efficacy with neuroprotective and immunomodulatory effects and a favourable benefit-risk profile. However, the effects of DMF on the immune system of MS patients were not clear before entering the market. During the last years, numerous in vitro and ex vivo studies have clarified the working mechanism of DMF in MS. Here, we discuss the pharmacokinetics of DMF and its effect on molecular immune-related pathways, which is further linked to the clinical and immunological effects of DMF treatment. The efficacy and safety of DMF treatment for RRMS is discussed as reported from clinical trials. Further, the immunological effects of DMF treatment in RRMS patients are addressed in more detail, including the distribution and function of immune cells. Taken together, evidence from recent studies points to a multifactorial working mechanism of DMF treatment in MS which leads to a restored immune balance favouring a more tolerogenic or anti-inflammatory immune profile.
\end{abstract}

\title{
Keywords
}

multiple sclerosis, dimethyl fumarate, adaptive immune system, innate immune system, B cells, $T$ cells, Nrf2, NF-kB 


\section{Introduction}

Multiple sclerosis (MS) is a chronic inflammatory disorder of the central nervous system (CNS) in which infiltrated autoreactive immune cells damage the myelin resulting in a chronic demyelinating and neurodegenerative disease (1). MS is generally diagnosed in young adults and affects approximately 2.3 million people worldwide $(1,2)$. Relapsing-remitting (RR) MS is the most common form of the disease that occurs in $80 \%$ of all MS patients and shows periods of clinical relapses alternated with periods of remission $(1,3)$. Different neuroanatomical locations are affected in MS, which results in a wide range of clinical symptoms such as sensory loss, fatigue, widespread weakness, blurred vision, depression and cognitive symptoms $(1,4)$. Within 20 years of diagnosis, half of the MS patients need mobility assistance and eventually develop extensive cognitive decline (1). MS is thought to have a multi-causal character, in which a combination of genetic and environmental risk factors are involved (1).

The pathogenesis of MS features CNS-directed autoimmune responses that lead to the formation of sclerotic plaques via demyelination, astrocytosis, oligodendrocyte depletion and axonal degeneration $(1,5)$. Autoreactive $C D 4^{+} T$ cells are activated in secondary lymphoid organs via molecular mimicry, bystander effects or cross-reactivity following a failure of tolerance checkpoints (6-9). These CD4 ${ }^{+} T$ cells migrate to the CNS where they are reactivated and produce inflammatory mediators such as cytokines and chemokines $(6,10)$. The inflammatory mediators attract other immune cells such as B cells, $\mathrm{CD} 8^{+} \mathrm{T}$ cells and macrophages. Together, the infiltrated immune cells cause an inflammatory reaction which leads to demyelinated lesions throughout the CNS $(5,9)$. Next to this "outside-in" model, the "inside-out" hypothesis states that the pathological processes in MS start in the CNS with the activation and infiltration of autoreactive lymphocytes occurring as a secondary event (10).

The immune system of MS patients is characterized by a dysregulated balance favouring proinflammatory responses. T cells have long been thought to be the most important players in MS pathogenesis. Effector memory CD4 ${ }^{+}$T cells can differentiate into T helper 1 (Th) 1 and Th17 cells, which produce pro-inflammatory cytokines including interferon- $\gamma$ (IFN- $\gamma$ ) or interleukin-17 (IL-17), respectively, and granulocyte macrophage colony-stimulating factor (GM-CSF) $(11,12)$. CD8 ${ }^{+} \mathrm{T}$ cells exert cytotoxic functions (13) while central memory $\mathrm{CD}^{+}{ }^{+} \mathrm{T}$ cells are prevalent in the cerebrospinal fluid of MS patients, provide help for B cell activation and stimulate dendritic cells (9). More recently, the emergence of $B$ cell depleting treatment has emphasized the importance of $B$ cells in MS pathogenesis $(10,14)$. Memory $B$ cells, both $\operatorname{IgD} D^{-} C D 27^{+}$class-switched memory $(C S M)$ and $\operatorname{lgD}{ }^{+} C D 27^{+}$ non class-switched memory (NCSM), are involved in MS pathology by antigen presentation, cytokine production and costimulation of T cells (15-17). Further, IgDCD27 double negative (DN) B cells with pro-inflammatory characteristics were recently described to be abnormally elevated in a proportion of MS patients (18). For the innate immune system, monocytes act as phagocytes, produce proinflammatory factors and reactive oxygen species (ROS) (9). Natural killer (NK) cells, including CD56 ${ }^{\text {dim }} C D 16{ }^{+}$NK cells and $\mathrm{CD} 56^{\text {bright }} \mathrm{CD} 16^{\text {dim }}$ NK cells, are involved in the pathogenesis of MS by a disrupted killing activity and a lowered suppression of $C D 4^{+} T$ cell proliferation (19-21). Responses of non-pathological and anti-inflammatory immune cells are underrepresented in MS, which is one of the underlying causes of the immune imbalance observed in MS patients (22-24). These nonpathological immune cells include naive T and B cells, T helper 2 (Th2) cells, producing IL-4, and regulatory $\mathrm{T}$ and $\mathrm{B}$ cells (Treg and Breg), producing IL-10. 
Dimethyl fumarate (DMF, Tecfidera ${ }^{\circledR}$, also known as BG-12) was licensed as the first oral first-line therapy for RRMS in 2013. Although it was known that DMF treatment had neuroprotective and immunomodulatory effects $(25,26)$, its multifactorial working mechanism was not fully unravelled at that time. In this review, we describe the molecular, clinical and immunological studies that have contributed to clarifying the mode of action of DMF.

\section{History of DMF as a therapeutic agent}

DMF is a fumaric acid ester, a small molecule with immunomodulating, anti-inflammatory and antioxidative effects. Fumaric acids are intermediates of the citric acid cycle in humans, which is used by cells to produce energy. Fumaric acid esters have been used for years as a therapy for psoriasis, a chronic inflammatory skin disease mediated by skin-directed T cells resulting in scaly plaques (27-29). In 1959 the chemist Schweckendiek, who suffered from psoriasis, hypothesized that psoriasis is caused by a disturbance in the citric acid cycle as a result of decreased levels of its component fumaric acid. As free fumaric acid has a gastrointestinal irritating effect and is poorly absorbed by the intestines, he developed a mixture of fumaric acid esters out of the Fumaria officinalis plant which cleared his psoriasis (30). Since 1994, a mixture of ethyl hydrogen fumarates and DMF (60\%) has been licensed in Germany as Fumaderm ${ }^{\circledR}$ for the systemic treatment of severe psoriasis. Studies of Fumaderm ${ }^{\circledast}$ reported high efficacy in psoriasis patients with an immunomodulatory potential of fumaric acid esters and a positive long-term safety profile, which made it a potential candidate for the treatment of MS (31-33). An exploratory open-label pilot study with Fumaderm ${ }^{\circledR}$ was conducted in 6 RRMS patients already in 2006. This study reported an improvement of disease activity by reducing the brain lesion number and volume after 18 weeks of treatment (34). Furthermore, this pilot study revealed immunomodulatory effects of fumaric acids in RRMS patients, such as an increase in anti-inflammatory IL-10 expressing CD4 ${ }^{+} \mathrm{T}$ cells. Regardless of the small number of included patients, this first study suggested that clinical trials of fumaric acid esters in RRMS patients were warranted (34).

\section{Pharmacokinetics of DMF}

DMF is hydrolysed into MMF by esterases in the small intestine. It was previously shown that an alkaline environment ( $\mathrm{pH} 8$ ), as is present in the small intestine, is necessary for this hydrolysis and that no hydrolysis of DMF occurs in an acidic environment $(\mathrm{pH} \mathrm{1)}$ resembling the stomach (35). Since only MMF and no DMF is detectable in the serum following DMF intake, it has long been thought that DMF is completely hydrolysed to $\operatorname{MMF}(36,37)$. However, it has become clear that one part of DMF is hydrolysed into MMF while another reacts with glutathione (GSH) to form long-lived GSHconjugates that were detected in the urine of DMF-treated psoriasis patients (37-40). Thus, both MMF and DMF can exert biologically relevant activities. Furthermore, lymphocytes and monocytes were shown to effectively hydrolyse MMF and DMF, which resulted in a faster removal of MMF and DMF from whole blood than from serum (35). Plasma levels of MMF are highly variable, ranging from 1 to $5 \mu \mathrm{g} / \mathrm{ml}$ (equivalent to $10-40 \mu \mathrm{M}$ ), and are dependent on food intake $(36,41)$. Furthermore, DMF and MMF are physiologically active between 5.5 and $50 \mu \mathrm{M}$ (toxic at $150 \mu \mathrm{M}$ ) and 50 and 150 $\mu \mathrm{M}$ (toxic at $450 \mu \mathrm{M}$ ), respectively (42). DMF and MMF exhibited a similar response profile in vitro but at distinctly different doses, namely $16.7 \mu \mathrm{M}$ for DMF and $150 \mu \mathrm{M}$ for MMF. Together, these findings could imply that different anatomic compartments and immune cell populations are exposed to different doses of DMF and MMF, which could have an influence on the working mechanism and therapeutic effects. 


\section{Molecular mechanism of action of DMF}

\subsection{Nuclear factor erythroid-derived 2 (Nrf2) pathway activation}

The neuroprotective effect of DMF and MMF is caused by activation of the transcription factor nuclear factor erythroid-derived 2 (Nrf2) (26). Nrf2 is expressed as a redox sensor in every cell of the body, including neurons, astrocytes, microglia and immune cells $(26,43,44)$. In vitro MMF treatment of human and rodent astrocytes led to a covalent modification of cysteine residue 151 of keap1 protein, which is the inhibitor or Nrf2 (Figure 1A) (26). This resulted in the dissociation of keap1 from Nrf2, Nrf2 activation and increased transcription of anti-oxidant target genes, including aldo-keto reductase family 1 member B10 (AKR1B10) and NADP(H) quinoline oxidoreductase-1 (NQO-1) (26). In this way, DMF/MMF could exert neuroprotective and cell survival effects $(26,45)$. Both DMF and MMF can covalently bind to cysteine residues of proteins via a process called protein succination. However, DMF and MMF have differing degrees of activity, which resulted in a greater accumulation of Nrf2 in human astrocytes treated in vitro with DMF than with MMF (46). In vivo, DMF treatment of mice with experimental autoimmune encephalomyelitis (EAE), the animal model for MS, induced an increase in free Nrf2 in neuronal and glial cells, resulting in a beneficial effect on disease score (26). This effect was almost completely abolished when using Nrf2 knockout mice.

However, EAE studies using Nrf2 knockout mice also showed that not all immune modulating activity of DMF is dependent of the Nrf2 pathway. DMF treatment of both Nrf2 knockout and wild-type mice reduced EAE susceptibility $(47,48)$. Further, both Nrf2 knockout and wild-type EAE mice showed reduced frequencies of Th1 and Th17 cells and reduced $B$ cell MHCll expression (48). In addition, downregulation of the adhesion molecule very late antigen-4 (VLA-4) was observed on T cells and B cells of EAE mice following DMF treatment in a Nrf2-independent manner (47). Other molecular pathways involved in the neuroprotective and immune modulating effects of DMF are described below.

\subsection{Nuclear factor (NF)-KB pathway inhibition}

$D M F$, but not MMF, was shown to interact with cysteines in several proteins involved in the nuclear factor (NF)-KB pathway, such as IKB kinase $\beta$ (IKK $\beta$ ). Consistent with these targets, DMF blocked the nuclear translocation of $p 65$ and $p 52$ in the NF-KB pathway (Figure 1B) $(42,49)$. One of the main targets of DMF was protein kinase C theta (PKC- $\theta$ ) (49), which is expressed in T cells where it is responsible for the engagement of the $T$ cell receptor and the costimulatory molecule CD28. By blocking cysteine residues in PKC- $\theta$, DMF inhibited IL-2 secretion by activated T cells (Figure 1C). Consequently, DMF inhibited the production of NF-KB driven pro-inflammatory factors such as IL-6, interferon- $\gamma$ induced protein 10 (IP10) and macrophage inflammatory protein (MIP)-1 $\beta$ by polyclonally stimulated human peripheral blood mononuclear cells (PBMCs) (42). Correspondingly, another study indicated that DMF but not MMF inhibited the nuclear binding of NF-KB in purified human T cells, although the used concentration of MMF was probably too low (50).

\subsection{Hydroxycarboxylic acid receptor 2 (HCAR2) activation}

The contribution of the hydroxycarboxylic acid receptor 2 (HCAR2) to the clinical efficacy of DMF was shown in EAE mice where DMF treatment had positive effects on disease score, immune cell infiltration and demyelination in wild-type but not HCAR2 knockout mice (51). HCAR2 is a G proteincoupled receptor that is expressed by immune cells such as macrophages, microglia, neutrophils, epidermal Langerhans cells and dendritic cells, but not by lymphocytes (52-57). HCAR2 was indicated 
to exert an anti-inflammatory effect by inhibiting transcription of NF-KB related genes, which led to a switch from classically activated pro-inflammatory microglia to alternatively activated antiinflammatory microglia in the CNS of EAE mice and the inhibition of pro-inflammatory molecule secretion (Figure 1D) (58). Further, HCAR2 activation was shown to induce apoptosis via decreasing cyclic adenosine monophosphate (AMP), to induce post-translational modification of B-cell lymphoma 2 (Bcl-2) family members and to reduce monocyte/macrophage chemotaxis and adhesion to endothelial cells $(53,57,59,60)$. The interaction of MMF with HCAR2 was also detected in vivo, since HCAR2 could cause flushing, a side effect of DMF treatment in MS patients, via the release of prostaglandin $2(52,61)$.

\subsection{Glutathione depletion}

Glutathione (GSH) is an anti-oxidant thiol that protects cells from oxidative stress, regulates cell proliferation, apoptosis and immune function (62). DMF can cause depletion of circulating GSH levels by binding to its free cysteines and forming GSH conjugates (Figure 1E) (63). Differential effects of DMF and MMF on GSH depletion from human astrocytes were observed, as DMF treatment transiently depleted intra- and extracellular GSH levels during $10 \mathrm{~h}$ after which GSH levels gradually increased while MMF increased GSH levels after $24 \mathrm{~h}$ of treatment (46). GSH depletion could contribute to the immunosuppressive and anti-inflammatory properties of DMF as it leads to an induction of the anti-inflammatory stress protein heme oxygenase 1 (HO-1), which reduces proinflammatory cytokine secretion in activated human PBMCs (64). The increase in total GSH after depletion may be a compensatory response or may be the result of GSH synthesis induced via the Nrf2 pathway by DMF and MMF (Figure $1 A)(46,62,65)$. Additionally, DMF can induce GSH recycling via increasing glutathione reductase (GSR) which catalyses glutathione disulphide (GSSG) reduction to GSH by using NADPH (Figure 1E). The increase in GSH is important for the neuroprotective effect of DMF since it makes the cells resistant against oxidative stress $(46,65,66)$.

\subsection{Inhibition of aerobic glycolysis}

DMF and MMF were shown to interact with cysteine residues of the glycolytic enzyme glyceraldehyde 3-phosphate dehydrogenase (GAPDH), both in vitro and in vivo (Figure 1F) $(67,68)$. Consequently, GAPDH is inactivated which results in an inhibition of the aerobic glycolysis in myeloid and lymphoid cells. Effector lymphocytes, such as Th1 and Th17 cells, require glycolysis for their proliferation, survival and effector functions such as cytokine production (69). On the contrary, differentiation of regulatory immune cells is driven by oxidative metabolism (68-70). Thus, DMF could mediate anti-inflammatory effects in lymphocytes by downregulating the glycolysis (68).

\section{Efficacy of DMF in animal models for MS}

Based on the results and the clinical success of the 2006 pilot study in RRMS patients (34), Schilling et al. investigated the efficacy of DMF in EAE (71). Prophylactic administration of DMF or MMF resulted in a decreased disease activity and reduced spinal cord infiltration of $T$ cells and macrophages compared to control animals receiving vehicle alone (71). Later, Linker et al. reported a reduced disease activity following both prophylactic and therapeutic DMF treatment in the chronic phase of EAE (26). DMF exerted neuroprotective effects reflected by a $60 \%$ reduction of demyelination, by neuronal and myelin preservation and by a reduced activation of astrocytes (26). In a spontaneous chronic EAE model in which both $T$ and $B$ cell receptors were specific for myelin oligodendrocyte glycoprotein (MOG), low dose DMF treatment resulted in a decreased disease activity, less 
demyelination and less macrophage infiltration in the spinal cord compared to control mice treated with vehicle alone and to mice treated with a high dose of DMF (72). Schulze-Topphoff et al. confirmed a reduced severity and incidence of spontaneous chronic EAE after DMF treatment (48). Furthermore, in an acute EAE model, combination treatment of DMF and IFN- $\beta$ ameliorated the EAE disease course (73). Hereby, DMF-treated mice showed higher axonal densities and milder demyelination compared to control mice receiving vehicle and compared to mice receiving IFN- $\beta$ monotherapy.

\section{Clinical trials of DMF treatment in RRMS patients}

\subsection{Efficacy}

In 2006, Biogen started to develop Tecfidera ${ }^{\circledR}$ for the treatment of RRMS. Tecfidera ${ }^{\circledR}$ is a combination of DMF and several galenics that improve gastric tolerability of the drug when compared to previous formulations (74). The efficacy of DMF in enteric-coated capsules in the treatment of RRMS in adults was evaluated in 2008 in a randomized, multi-center, double blind, placebo controlled phase II trial (75). Patients were randomized to receive either placebo, $120 \mathrm{mg}$ DMF once daily, $120 \mathrm{mg}$ DMF three times daily or $240 \mathrm{mg}$ DMF three times daily for 24 weeks. The mean total number of new gadolinium enhancing (GdE) lesions on brain magnetic resonance imaging (MRI, primary endpoint) was reduced by $69 \%$ from week 12 to 24 in the $240 \mathrm{mg}$ three times daily treated RRMS patients (75). Subsequently, two phase III trials were conducted, namely Determination of the Efficacy and Safety of Oral Fumarate in RRMS (DEFINE) and Comparator and an Oral Fumarate In RRMS (CONFIRM) $(61,76)$. The DEFINE study was a double blind study where patients were randomly assigned to receive either placebo, DMF at $240 \mathrm{mg}$ twice daily or three times daily. The proportion of RRMS patients who had a relapse within 2 years of DMF treatment (primary endpoint, $27 \%$ for DMF twice daily and $26 \%$ for DMF three times daily) reduced significantly compared to placebo (46\%) (61). In the CONFIRM study, patients were randomly assigned to receive placebo, DMF twice or three time daily and patients taking glatiramer acetate were used as a comparator. After 2 years of treatment, the annualized relapse rate (primary endpoint) was significantly reduced in the two DMF-treated groups ( 0.22 for DMF twice daily and 0.20 for DMF three times daily) and the glatiramer actetate treated group (0.29) compared to placebo (0.40) (76). As a result, DMF was approved by the Food and Drug Administration (FDA) and the European Medicines Agency (EMA) to be prescribed as a first-line therapy for RRMS patients at a dosing of 240 mg twice a day. Integrated analyses of the two phase III studies showed a high efficacy of DMF in newly diagnosed RRMS patients with a low EDSS score (77).

Disability was measured using the Multiple Sclerosis Functional Composite (MSFC) in the DEFINE and CONFIRM studies (78). The MSFC assesses motor function of the leg and ambulation with the Timed 25-Foot Walk (T25W), arm and hand function with the 9-Hole Peg Test (9HPT), and cognitive function with Paced Auditory Serial Addition Test (PASAT-3). MS patients treated with DMF showed an improved and superior MSFC compared to placebo (78). These results were reinforced by our own study, including mostly newly diagnosed RRMS patients, since 9/9 and 7/9 DMF-treated MS patients demonstrated a stable T25W and 9HPT, respectively, and an improvement was detected in the PASAT-3 score after 1 year of DMF treatment compared to baseline (79). 


\subsection{Safety}

The DEFINE and CONFIRM studies showed mild to moderate side effects of DMF including gastrointestinal events and flushing which decreased after $1-2$ months $(61,76)$. To increase tolerability, patients are recommended to start with $120 \mathrm{mg}$ for a week after which the dose should be increased up to $240 \mathrm{mg}$ twice a day. The patients of the DEFINE and CONFIRM studies were followed for another 3 years in a long-term extension study (ENDORSE), which resulted in a total follow-up of 5 years (80). The safety profile of DMF was acceptable and comparable with the DEFINE/CONFIRM studies. However, a case of progressive multifocal leukoencephalopathy (PML), an opportunistic brain infection caused by the John Cunningham (JC) virus, was reported in a DMF-treated MS patient with severe prolonged lymphopenia (81). In 2016, already four other cases of PML were reported (81). Nonetheless, in RRMS patients continuing DMF treatment, mean white blood cells and lymphocyte counts remained stable throughout time (80). To reduce the risk of PML, it is recommended to monitor lymphocyte counts before treatment and every 3 months (EMA) or every 6-12 months (FDA) thereafter. Discontinuation of DMF should be considered for MS patients experiencing lymphopenia ( $<500$ cells $/ \mathrm{mm} 3$ ) persisting for more than 6 months ( 80$)$.

In conclusion, clinical trials of DMF have shown strong efficacy and a sustained and favourable benefit-risk profile for RRMS patients. Detailed analysis of clinical parameters indicated that DMF treatment protects MS patients from a progressive decline in motor and cognitive function.

\section{Immunological studies of DMF treatment in RRMS patients}

Several studies have investigated the effects of DMF treatment on immune cell number, frequency and function in RRMS patients. An overview of these studies and the most important reported effects of DMF treatment are presented in Figure 2 and Tables 1-3.

\subsection{Effects of DMF treatment on the number and frequency of immune cell subtypes}

DMF treatment has been shown to have immunosuppressive effects. In addition, differential effects on the distribution of specific immune cell subtypes have been demonstrated.

\subsubsection{DMF treatment can induce lymphopenia}

DMF treatment significantly decreased the total number of leukocytes and lymphocytes (Table 1), however it did not affect the number of monocytes, neutrophils and basophils $(82,83)$. This suggests that DMF particularly targets the adaptive immune system. Fleisher et al. found an association between lymphopenia and disease activity with a lower number of T cells, NK cells and B cells in lymphopenic versus non-lymphopenic DMF-treated MS patients (84). Similar results were reported at the same time by Chaves et al., although NK cells were not affected in this study (85). Lymphopenia could thus protect DMF-treated MS patients from inflammatory MS disease activity, although it is also a risk factor for the development of PML. An integrated analysis of phase $\mathrm{Ilb} / \mathrm{III}$ long-term extension studies (DEFINE, CONFIRM, ENDORSE) in MS patients treated with DMF for 1-7 years indicated an incidence of grade 3 lymphopenia of $7 \%$ (86). An absolute lymphocyte number lower than $500 / \mathrm{mm}^{3}$ persisting for more than 6 months was proposed as effective early predictor for developing prolonged lymphopenia. Following one year of DMF treatment, the absolute lymphocyte number remained stable (86). In conclusion, the risk of PML should be taken into consideration, although the monitoring of the absolute lymphocyte number could reduce this risk, and long-term use of DMF results in a stable absolute lymphocyte number. 


\subsubsection{DMF treatment preferentially reduces cytotoxic T cells}

When considering the absolute number of lymphocyte subtype populations, DMF treatment decreased $B$ cells, $C D 4^{+} T$ cells and $C D 8^{+} T$ cells (Figure 2 , Table 2,3$)(67,82-84,87,88)$. However, several studies indicated an increased $\mathrm{CD} 4^{+} / \mathrm{CD}^{+} \mathrm{T}$ cell ratio after DMF treatment, indicating a preferential loss of $\mathrm{CD}^{+} \mathrm{T}$ cells $(67,82-84,87,88)$. This reduction of $\mathrm{CD} 8^{+} \mathrm{T}$ cells is a general characteristic of DMF treatment since it was also detected in psoriasis patients treated with Fumaderm (89). When compared to MS patients with active disease, MS patients with a stable disease course presented with a lower number of lymphocytes, $C D 4^{+} T$ cells, $C D 8^{+} T$ cells and $B$ cells and an increased $\mathrm{CD} 4^{+} / \mathrm{CD}^{+} \mathrm{T}$ cell ratio following DMF treatment (84). Moreover, the number of $\mathrm{CD}^{+} \mathrm{T}$ cells, lymphocytes and $\mathrm{B}$ cells were indicated as predictors of treatment response (84). Additionally, the number of $C D 8^{+} T$ cells was preferentially decreased compared to $C D 4^{+} T$ cells and $B$ cells in lymphopenic DMF-treated MS patients when compared to non-lymphopenic DMF-treated MS patients $(84,85)$.

In the studies of Khatri et al. and Spencer et al., a decline of CD8 ${ }^{+} \mathrm{T}$ cells below the lower limit of normal (LLN, 200 cells/ $\mu$ l) was observed in half or the majority of the DMF-treated MS patients, respectively $(82,88)$. Since $C D 8^{+} \mathrm{T}$ cells are thought to contribute to the defence against the JC virus, it was suggested that a sustained reduction of $C D 8^{+} T$ cells could be a risk factor for $\operatorname{PML}(82,88)$. However, we previously identified only $14 \%$ of the DMF-treated MS patients with a $\mathrm{CD} 8^{+} \mathrm{T}$ cell number below the LLN in our longitudinal study (79). The inclusion of older MS patients previously treated with second-line treatments in the first studies and the lower patient number in the latter study could account for the discrepancy in $\mathrm{CD}^{+} \mathrm{T}$ cell number.

In conclusion, we and other research groups have observed that one of the important effects of DMF treatment in $\mathrm{MS}$ is the reduction of $\mathrm{CD} 8^{+} \mathrm{T}$ cells.

\subsubsection{DMF treatment preferentially reduces memory and effector memory $T$ and B cells}

When analysing the absolute number of $B$ and $T$ cell subtypes, we showed a decreased absolute number of memory $\mathrm{CD}^{+}$and $\mathrm{CD} 8^{+} \mathrm{T}$ cells, memory $\mathrm{B}$ cells (class-switched and non class-switched) and DN B cells after 12 months of DMF treatment (79). Naive CD4 ${ }^{+}$and $\mathrm{CD} 8^{+} \mathrm{T}$ cells, naive and transitional B cells, that are not involved in MS pathology, were decreased or unchanged following DMF treatment (Table 2, 3) (79). Li et al. showed that already after 3 months of DMF treatment, mature and differentiated $B$ cells, but not transitional $B$ cells, are preferentially lost in the circulation (Table 3) (90). These data suggest that the output of immature $B$ cells from the bone marrow is not prevented by DMF $(79,90)$.

Next to the absolute cell number, it is important to consider the frequencies of the immune cell subtypes in order to determine the changes in the relative composition of the remaining cell population following DMF treatment. Several groups have shown that DMF treatment decreased the frequencies of central memory and effector memory $\mathrm{CD} 4^{+}$and $\mathrm{CD} 8^{+} \mathrm{T}$ cells, while naive $\mathrm{CD} 4^{+}$and $\mathrm{CD}^{+} \mathrm{T}$ cell frequencies were increased in DMF-treated MS patients (Figure 2, Table 2) $(25,79,83,91$, 92). Medina et al. reported similar effects of DMF treatment on effector memory and naive $T$ cells but could not confirm the decrease in central memory $T$ cell subtypes (93). This discrepancy with the other studies could be due to the limited follow-up period of 6 months in the latter study. Ghadiri et 
al. showed a continued reduction in the frequency of central memory T cells after 6 months that was statistically significant after 12 months of DMF treatment (91). DMF treatment exhibited similar effects on B cells by decreasing the frequencies of non class-switched memory B cells, class-switched memory B cells and DN B cells while increasing naive and transitional B cells in MS patients (Figure 2, Table 3) (79, 93-95).

In conclusion, depletion of memory and effector memory $T$ and $B$ cells is one of the effects of DMF in MS (Figure 2). In this way, DMF is capable of redirecting the disrupted immune balance of MS patients away from the pro-inflammatory immune response.

\subsubsection{DMF treatment increases the anti-inflammatory Treg and Breg}

Differences are found concerning the effect of DMF treatment on the frequency of Treg. Most studies did not find a change in the frequency of Treg ( $\mathrm{CD} 4^{+} \mathrm{CD} 127^{\text {low }} \mathrm{CD} 25^{+}$or $\left.\mathrm{CD} 4^{+} \mathrm{CD} 25^{+} \mathrm{Foxp}^{+}\right)$in DMF-treated MS patients $(79,91-94)$. However, Treg can be subdivided into different subtypes depending on the expression of several functional markers (96-98). Longbrake et al. did not find an effect of DMF treatment on the CD39+ Treg subtype (Table 2) (94), which was previously shown to suppress IFN- $\gamma$ and IL-17 production by effector cells more efficiently than CD39- Treg (99). Further, Gross et al. reported an increase in the frequency of the peripheral derived Treg $\left(\mathrm{CD} 4^{+} \mathrm{CD} 127^{\text {low }} \mathrm{CD} 25^{\text {high }} \mathrm{FoxP3}^{+}\right.$Helios) under DMF treatment (Table 2) (25). DMF can thus influence specific Treg subtypes and more research is needed to evaluate this further.

The frequency of transitional B cells, that can differentiate into Breg, was increased following DMF treatment in MS patients (Table 3) (79). Lundy et al. described an increase in the frequency of Breg in DMF-treated MS patients although the extent of the increase varied greatly between patients, a finding that might explain the lack of an effect on Breg in the study of Medina et al. (Table 3) (93, 100). Furthermore, using in vitro experiments we showed that DMF could directly increase the frequency of Breg (79). Breg suppress Th1 and Th17 cell differentiation while inducing the generation of Treg and could therefore contribute to the efficacy of DMF in MS treatment (101).

Taken together, DMF has the capacity to increase the frequency of

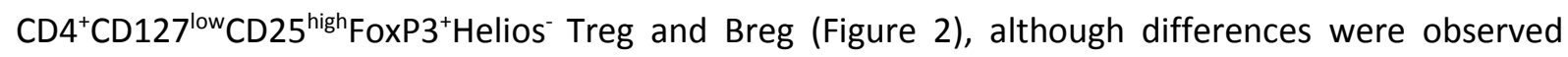
between studies. These data again contribute to the DMF induced shift in the immune balance to a more anti-inflammatory profile.

7.1.5 DMF treatment decreases the CD56 ${ }^{\mathrm{dim}} \mathrm{NK}$ cell number and increases the CD56 ${ }^{\text {bright }}$ NK cell frequency

The absolute number and frequency of total NK cells was not changed in DMF-treated MS patients $(83,85,93,102)$. However, when considering different subtypes of NK cells, DMF treatment was shown to decrease the absolute number of CD56 dim NK cells while CD56 $6^{\text {bright }}$ NK cells were not affected in a cross-sectional study but increased in 2 follow-up studies (Figure 2, Table 1) (79, 92, 102). Further, the frequency of CD56 bright NK cells was increased to a greater extent than the frequency of CD56 ${ }^{\text {dim }}$ NK cells in DMF-treated MS patients (Table 1) $(79,93)$. CD56 bright NK cells have been considered to be different from CD56 ${ }^{\text {dim }}$ NK cells because they showed a reduced cytotoxicity and an enhanced cytokine production (19). The beneficial role of CD56 bright NK cells in the pathogenesis of MS patients was highlighted when their expansion was correlated with the efficacy 
of daclizumab, a humanized anti-CD25 monoclonal antibody, in MS treatment (103). Since CD56 bright NK cells can lyse autoreactive $T$ cells, harbour a high migratory capacity across the blood-brain barrier and are enriched in the cerebrospinal fluid of MS patients $(104,105)$, they are potentially important to limit autoimmunity following DMF treatment.

\subsection{Effects of DMF treatment on the function of immune cells}

When considering the function of specific immune cell subtypes, DMF has been reported to affect the cytolytic function of NK cells, apoptosis, cytokine production, T cell activation and proliferation and $B$ cell costimulation and antigen presentation.

\subsubsection{DMF treatment restores the cytolytic function of NK cells}

Although DMF treatment increased the frequency of CD56 bright NK cells in MS patients, it is also important to investigate the effect of DMF on the killing activity of NK cells as this NK cell function is disrupted in MS patients and is correlated with symptomatic relapse (21). In vitro treatment of human NK cells with MMF increased the killing activity of CD56 ${ }^{+}$NK cells but not of CD56- NK cells towards tumor cells $(106,107)$. Furthermore, NK cells of DMF-treated MS patients presented with an increased cell degranulation and cytotoxicity towards activated autologous $T$ cells when treated with DMF or MMF compared to vehicle (Figure 2) (102). Expression of CD155, involved in NK cell cytolysis (104), was preferentially expressed on $\mathrm{CD}^{+} \mathrm{T}$ cells and central memory $\mathrm{T}$ cells compared to $\mathrm{CD} 4^{+} \mathrm{T}$ cells and naive T cells, respectively (102). This could point to the involvement of CD56 bright NK cells in the preferential loss of memory $\mathrm{CD}^{+} \mathrm{T}$ cells, which was also suggested by the finding of a negative correlation between the frequency of $C D 56^{\text {bright }} \mathrm{NK}$ cells and memory $\mathrm{CD} 8^{+} \mathrm{T}$ cells $(93,102)$. In conclusion, the restored cytolytic function of NK cells in DMF-treated MS patients could play a role in controlling autoimmunity via preferential targeting of $\mathrm{CD} 8^{+} \mathrm{T}$ cells and memory $\mathrm{T}$ cells.

\subsubsection{DMF treatment induces apoptosis of immune cells}

Several studies investigated whether the reduction in peripheral blood lymphocyte subtypes in DMFtreated MS patients was the result of apoptosis of these cells. DMF, but not MMF, was shown to induce a dose- and time-dependent apoptosis of preferably activated human $\mathrm{T}$ cells (CD4 ${ }^{+}, \mathrm{CD} 8^{+}$and memory) by downregulating Bcl-2 expression (Figure 2) (108). When considering T cell subtypes, Ghadiri et al. and Wu et al. detected a preferential effect of DMF on apoptosis induction of $\mathrm{CD} 8^{+} \mathrm{T}$ cells compared to $C D 4^{+} T$ cells of healthy controls $(83,91)$. Moreover, central memory and effector memory $\mathrm{CD}^{+}$and $\mathrm{CD}^{+}{ }^{+}$cells exhibited greater susceptibility to DMF-induced apoptosis compared to naive T cells and Treg (91). For B cells, we showed that in vitro treatment with DMF, but not MMF, induced apoptosis of polyclonally stimulated B cells from healthy controls and untreated MS patients in a concentration-dependent manner with B cells of MS patients appearing to be more vulnerable (79). Additionally, Li et al. detected a preferential effect of in vitro DMF induced apoptosis on mature B cells compared to transitional B cells of healthy controls (90). In conclusion, these data suggest that DMF but not MMF can directly induce apoptosis in T cells and B cells and the preferential reduction of $\mathrm{CD}^{+} \mathrm{T}$ cells and memory immune cell subtypes detected ex vivo in DMF-treated MS patients can be the result of their greater susceptibility to DMF-induced apoptosis.

\subsubsection{DMF treatment inhibits pro-inflammatory cytokines}

Several studies indicated reduced frequencies of pro-inflammatory GM-CSF ${ }^{+}, \mathrm{IFN}-\gamma^{+}, \mathrm{TNFa}^{+}, \mathrm{IL}-22^{+}$ and IL- $17^{+} \mathrm{CD} 4^{+} \mathrm{T}$ cells of DMF-treated MS patients following ex vivo stimulation, while the frequency 
of $\mathrm{IL}-4^{+}$and IL- $10^{+} \mathrm{CD} 4^{+} \mathrm{T}$ cells remained unchanged (Figure 2$)(25,79,83,91,94)$. However, another

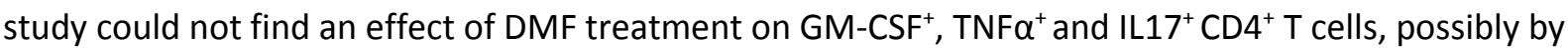
the use of different stimulation conditions (93). Furthermore, the latter study was limited to 6 months of follow-up while our study as well as the study of Wu et al. showed that IL17 $7^{+} \mathrm{CD} 4^{+} \mathrm{T}$ cells were reduced after a longer period of DMF treatment $(79,83,93)$. For $\mathrm{CD}^{+} \mathrm{T}$ cells, DMF treatment reduced the frequency of pro-inflammatory IFN $-\gamma^{+}$and TNF- $\alpha^{+} \mathrm{CD} 8^{+} \mathrm{T}$ cells while the frequency of IL$10^{+} \mathrm{CD}^{+} \mathrm{T}$ cells did not change in MS patients (Figure 2$)(91,93,94)$. Medina et al. further described an increased frequency of $\mathrm{GM}^{-\mathrm{CSF}^{+}} \mathrm{CD}^{+} \mathrm{T}$ cells (93) which was not confirmed by Longbrake et al. (94).

Similar to its effect on T cells, DMF treatment decreased the absolute number and frequency of proinflammatory TNF- $\alpha^{+}, \mathrm{GM}-\mathrm{CSF}^{+}$and IL- $6^{+}$B cells while no effect was observed on IL-10 $\mathrm{B}$ cells in MS patients (Figure 2) $(90,95)$. When analysing $B$ cells of DMF-treated MS patients stimulated in vitro with CD40 ligand, Lundy et al. found an increased B cell IL-10 production following 4-6 months of treatment compared to baseline (100). In addition, reductions of IFN- $\mathrm{y}^{+} \mathrm{CD} 4^{+}$and $\mathrm{CD} 8^{+} \mathrm{T}$ cells, TNF- $\alpha^{+}$ $\mathrm{CD}^{+} \mathrm{T}$ cells and $\mathrm{B}$ cells could be predictors for stable disease in DMF-treated MS patients (93). In conclusion, DMF treatment shifts the inflammatory Th1, Th17 and B cell response to a more tolerogenic response in MS patients.

\subsubsection{DMF treatment inhibits T cell activation and proliferation}

DMF treatment has been shown to interfere with the activation and proliferation of $T$ cells. The frequency of activated $\mathrm{CD} 69^{+} \mathrm{T}$ cells was reduced in DMF-treated MS patients, particularly in the memory T cell subtype and even beyond 18 months of treatment (Figure 2) (83). DMF directly inhibited activation of $T$ cells from healthy controls, as shown by in vitro experiments (83). DMF further interferes with immune cell activation by blocking aerobic glycolysis of lymphoid cells by inactivation GAPDH, as described above (Figure 1F) (68). In addition, DMF directly inhibited T cell proliferation in a dose-dependent manner whereby $\mathrm{CD} 8^{+} \mathrm{T}$ cells were more vulnerable than $\mathrm{CD} 4^{+}$or total $\mathrm{CD}^{+} \mathrm{T}$ cells (83). Interestingly, this anti-proliferative effect was alleviated under in vivo DMF treatment of MS patients (67). The anti-proliferative function of DMF is probably the result of the reduced nuclear translocation of the p65 subunit of NF-KB in PBMCs (Figure 1B) (67). Although DMF treatment did not abrogate the generation and release of $\mathrm{CD}^{+}$recent thymic emigrants (RTEs), the resulting increased frequency of new $\mathrm{CD}^{+} \mathrm{T}$ cells was not sufficient to replete the DMF induced $\mathrm{T}$ cell loss (91).

It has been suggested that DMF could protect the immune cells from oxidative stress via activation of the Nrf2 signaling pathway (26). Indeed, DMF reduced levels of reactive oxygen species (ROS) in activated T cells of healthy controls in vitro (83). However, in MS patients, DMF treatment induced oxidative stress in T cells, which was shown by increased levels of cytosolic oxidants in T cells, decreased levels of anti-oxidative compounds and increased GSH metabolism in serum of DMFtreated MS patients (67). This increased oxidative stress in T cells contributes to both the inhibition of $\mathrm{T}$ cell proliferation and induction of apoptosis by DMF (67) and in turn also to the in vivo redistribution of $T$ cell subtypes.

Additionally, one study reported a repair of the Treg suppression capacity, which is decreased in treatment naive MS patients (109), in DMF-treated MS patients by reducing the IL-6 receptor on 
effector T cells (110). Together, DMF treatment dampens the response of pro-inflammatory effector $\mathrm{T}$ cells in MS by blocking their activation and proliferation and making them more responsive for suppression by Treg.

\subsubsection{DMF treatment interferes with antibody-independent functions of B cells}

DMF treatment did not change serum levels of total immunoglobulin $M(\operatorname{IgM})$, IgG or $\lg A$, nor did it change the frequencies of $\operatorname{IgG}^{+}, \operatorname{IgM}^{+}$or $\operatorname{lgA}^{+} B$ cells in $\mathrm{MS}$ patients $(67,79,94)$. Ex vivo analysis indicated a decrease in $B$ cell expression of surface markers that are important for $B$ cell $-T$ cell interactions, such as CD11C, CD43, CD80 and CD83, following DMF treatment (Figure 2) (90). Longbrake et al. detected a decrease in the frequency of $\mathrm{CD} 80^{+}$non class-switched memory $\mathrm{B}$ cells while $C D 86^{+}$B cell subtypes were not affected in DMF-treated MS patients (94). Furthermore, our study demonstrated that DMF directly decreased expression of antigen presentation molecule HLA$\mathrm{DR} / \mathrm{DP} / \mathrm{DQ}$, costimulatory molecule CD40 and survival marker B-cell activating factor receptor (BAFFR) on B cells of MS patients using in vitro experiments (Figure 2) (79). In addition, polyclonal activation of $B$ cells from DMF-treated MS patients could be eliminated and even inversed by in vitro DMF stimulation via decreasing CD40, CD86 and CD150 expression (67). Interestingly, after 3 months of DMF treatment the activation potential of B cells decreased in MS patients compared to baseline (67). In conclusion, DMF downregulates expression of functional markers on B cells which are involved in antigen presentation, B cell activation and survival. This contributes to the clinical effect and the reduction of the autoimmune response in DMF-treated MS patients.

\section{Conclusions}

DMF is considered to be a treatment with a strong persistent efficacy and a favourable benefit-risk profile for RRMS patients. It reduces the relapse rate and the number of brain lesions and thereby protects MS patients from a further decline in motor and cognitive function. Because of the convenient oral administration, DMF provides an alternative for MS patients who refuse or cannot tolerate injectable therapies because of anxiety or injection related effects. The mechanism behind the beneficial clinical effect of DMF in MS patients is multifactorial and is still being unravelled. In general, DMF has an immune modulating effect shifting the disturbed immune balance of MS patients away from the pro-inflammatory profile. DMF treatment selectively reduces $\mathrm{CD} 8^{+} \mathrm{T}$ cells and inflammatory memory subtypes of T and B cells while increasing Treg and Breg in MS patients. This is partly due to the restored cytolytic function of CD56 bright NK cells in DMF-treated MS patients. Furthermore, pro-inflammatory cytokine expression or production by $\mathrm{T}$ cells and $\mathrm{B}$ cells is reduced in DMF-treated MS patients, shifting the Th1/Th17 and pro-inflammatory B cell response to an antiinflammatory response. Functionally, DMF treatment inhibits the activation and proliferation of $T$ cells as well as the expression of antigen presentation and costimulatory markers on B cells. The molecular mechanism behind the selective reductions of specific immune subtypes can be explained by the interference of DMF in several molecular pathways (Nrf2, NF-kB, HCAR2, GSH, glycolysis) via covalently modifying different cysteine residues of molecules in these pathways. In conclusion, DMF treatment can reduce the autoimmune processes in MS pathogenesis via inhibiting the proinflammatory immune cells by interfering with the molecular mechanism responsible for their harmful functions and by enhancing regulatory immune cells. 


\section{Take home messages}

- DMF treatment has a favourable benefit-risk profile in MS patients.

- DMF treatment is an immune modulating therapy that preferentially targets $C D 8^{+} T$ cells and proinflammatory memory $\mathrm{T}$ and $\mathrm{B}$ cells in MS patients.

- Treg and Breg frequencies can be enhanced by DMF treatment in MS patients.

- The preferential reduction of $\mathrm{CD} 8^{+} \mathrm{T}$ cells and memory immune cells is probably due their higher susceptibility for DMF-induced apoptosis, interference with aerobic glycolysis and decreased activation and proliferation.

- DMF treatment inhibits the pro-inflammatory functions of immune cells such as cytokine production by $T$ and $B$ cells, antigen presentation and costimulation by $B$ cells and induces apoptosis in immune cells.

- Neuroprotective effects of DMF and reduction of the pro-inflammatory response in MS patients by DMF treatment can be regulated via activation of the Nrf2 and the HCAR2 pathways and inhibition of the NF-KB pathway. 
Table 1. The effects of DMF on lymphocyte and monocyte number and frequency

$\mathrm{DMF}=$ dimethyl fumarate, $\mathrm{m}=$ months, $\mathrm{NK}=$ natural killer cell, $\mathrm{HC}=$ healthy control, $\mathrm{UT}=$ untreated.

\begin{tabular}{|c|c|c|c|c|}
\hline $\begin{array}{l}\text { Immune cell } \\
\text { subtype }\end{array}$ & Effect of DMF treatment & $\begin{array}{l}\text { Duration } \\
\text { (m) }\end{array}$ & Study design & Reference \\
\hline \multirow[t]{3}{*}{ Leukocytes } & \multirow[t]{2}{*}{ Number: decreased } & 12 & Follow-up & (82) \\
\hline & & $4-6,18-26$ & Cross-sectional & $(83),(84)$ \\
\hline & Percentage: decreased & 12 & Follow-up & $(67,79)$ \\
\hline \multirow[t]{2}{*}{ Lymphocytes } & \multirow[t]{2}{*}{ Number: decreased } & $3,6,9,12$ & Follow-up & $\begin{array}{l}(67,79,82 \\
87,88,91,95)\end{array}$ \\
\hline & & $4-6,18-26$ & Cross-sectional & (83), (84) \\
\hline \multirow[t]{2}{*}{ Monocytes } & \multirow[t]{2}{*}{ Number: no effect } & 12 & Follow-up & $(67,79,82)$ \\
\hline & & $4-6,18-26$ & Cross-sectional & (83), (84) \\
\hline \multirow[t]{2}{*}{ Total NK cells } & Number: no effect & $4-6,18-26$ & $\begin{array}{l}\text { Follow-up } \\
\text { Cross-sectional }\end{array}$ & (83) \\
\hline & Percentage: no effect & 6 & Follow-up & (93) \\
\hline \multirow{4}{*}{$\begin{array}{l}\text { CD56 bright NK } \\
\text { cells }\end{array}$} & \multirow[t]{2}{*}{ Number: no effect } & 12 & Follow-up & (82) \\
\hline & & $\geq 6$ & Cross-sectional & $(84,92)$ \\
\hline & $\begin{array}{l}\text { Number + percentage: } \\
\text { decreased }\end{array}$ & 12 & Follow-up & $\begin{array}{l}(67) \\
(79)\end{array}$ \\
\hline & Percentage: increased & 6 & Follow-up & (93) \\
\hline \multirow[t]{2}{*}{ CD56 dim NK cells } & $\begin{array}{l}\text { Number: decreased; } \\
\text { Percentage: increased }\end{array}$ & 12 & Follow-up & (79) \\
\hline & Number: decreased & $\geq 6$ & Cross-sectional & (92) \\
\hline \multirow[t]{2}{*}{ NKT cells } & Number: decreased & $18-26$ & $\begin{array}{l}\text { Follow-up } \\
\text { Cross-sectional }\end{array}$ & (83) \\
\hline & Percentage: decreased & 6 & Follow-up & (93) \\
\hline
\end{tabular}


Table 2. The effects of DMF on T cell number and frequency

$\mathrm{DMF}=$ dimethyl fumarate, $\mathrm{m}=$ months, $\mathrm{HC}=$ healthy control, $\mathrm{UT}=$ untreated, NEDA = no evidence of disease activity, Treg = regulatory $\mathrm{T}$ cell.

\begin{tabular}{|c|c|c|c|c|}
\hline $\begin{array}{l}\text { Immune cell } \\
\text { subtype }\end{array}$ & Effect of DMF treatment & Duration $(\mathrm{m})$ & Study design & Reference \\
\hline \multirow[t]{3}{*}{$\mathrm{CD}^{+} \mathrm{T}$ cells } & \multirow[t]{2}{*}{ Number: decreased } & $4,6,12$ & Follow-up & $\begin{array}{l}(67,79,82 \\
87,91)\end{array}$ \\
\hline & & 6 & Cross-sectional & (84) \\
\hline & Percentage: no effect & 6 & Follow-up & (25) \\
\hline \multirow[t]{3}{*}{$\mathrm{CD}^{+} \mathrm{T}$ cells } & \multirow[t]{2}{*}{ Number: decreased } & $\begin{array}{l}3,4,6,9,12 \\
18-26\end{array}$ & Follow-up & $\begin{array}{l}(67,79,82, \\
83,87,88,91)\end{array}$ \\
\hline & & $\begin{array}{l}4-6, \geq 6,18- \\
26\end{array}$ & Cross-sectional & $(83,84,92)$ \\
\hline & Percentage: no effect & 6,12 & Follow-up & $(25,79,93)$ \\
\hline \multirow[t]{3}{*}{$\mathrm{CD}^{+} \mathrm{T}$ cells } & \multirow[t]{2}{*}{ Number: decreased } & $\begin{array}{l}3,4,6,9,12 \\
18-26\end{array}$ & Follow-up & $\begin{array}{l}67,79,82 \\
83,87,88,91)\end{array}$ \\
\hline & & $\begin{array}{l}4-6, \geq 6,18- \\
26\end{array}$ & Cross-sectional & $(83,84,92)$ \\
\hline & Percentage: decreased & 6 & Follow-up & $(25,79,93)$ \\
\hline \multirow[t]{3}{*}{$\begin{array}{l}\mathrm{CD}^{+} \mathrm{T} \text { cell } \\
\text { subtypes }\end{array}$} & $\begin{array}{l}\text { Number memory: decreased; } \\
\text { Number naive: no effect }\end{array}$ & 12 & Follow-up & (79) \\
\hline & \multirow{2}{*}{$\begin{array}{l}\text { Percentage naive: increased; } \\
\text { Percentage (effector) memory: } \\
\text { decreased }\end{array}$} & $3,6,12$ & Follow-up & $\begin{array}{l}(25,67,79, \\
83,91,93)\end{array}$ \\
\hline & & $\begin{array}{l}4-6,6-12 \\
>12\end{array}$ & Cross-sectional & $(79,83,92)$ \\
\hline \multirow[t]{4}{*}{$\begin{array}{l}\mathrm{CD}^{+} \mathrm{T} \text { cell } \\
\text { subtypes }\end{array}$} & $\begin{array}{l}\text { Number memory: decreased; } \\
\text { Number naive: no effect }\end{array}$ & 12 & Follow-up & (79) \\
\hline & $\begin{array}{l}\text { Percentage effector memory: } \\
\text { decreased; Percentage naive: } \\
\text { no effect }\end{array}$ & 3 & Follow-up & (67) \\
\hline & \multirow{2}{*}{$\begin{array}{l}\text { Percentage naive: increased; } \\
\text { Percentage (effector) memory: } \\
\text { decreased }\end{array}$} & $6,12,18-26$ & Follow-up & $\begin{array}{l}(25,79,83 \\
91,93)\end{array}$ \\
\hline & & $\begin{array}{l}4-6,6-12 \\
>12,18-26\end{array}$ & Cross-sectional & $(79,83,92)$ \\
\hline \multirow[t]{5}{*}{ Treg } & \multirow{2}{*}{$\begin{array}{l}\text { Number: decreased; } \\
\text { Percentage: no effect } \\
\left(\mathrm{CD} 25^{\text {hi }} \mathrm{CD} 127^{\text {low }}, \mathrm{CD} 127^{+} \mathrm{Foxp}^{+}\right)\end{array}$} & 6,12 & Follow-up & $(79,91,93)$ \\
\hline & & $\geq 6$ & Cross-sectional & (92) \\
\hline & $\begin{array}{l}\text { Percentage: increased } \\
\left(\mathrm{CD} 25^{+} \mathrm{CD} 127^{-} \text {Foxp }^{+}\right)\end{array}$ & 3 & Follow-up & (67) \\
\hline & $\begin{array}{l}\text { Percentage: increased } \\
\left(\mathrm{CD} 127^{\text {low }} \mathrm{CD} 25^{\text {hi }} \text { Foxp3 }{ }^{+} \text {Helios }^{-}\right)\end{array}$ & 6 & Follow-up & (25) \\
\hline & $\begin{array}{l}\text { Percentage: no effect (CD39 } \\
\text { Treg) }\end{array}$ & $6-30$ & Cross-sectional & (94) \\
\hline
\end{tabular}


Table 3. The effect of DMF treatment on B cells

$\mathrm{DMF}=$ dimethyl fumarate, $\mathrm{m}=$ months, $\mathrm{HC}=$ healthy control, $\mathrm{UT}=$ untreated, $\mathrm{CSM}=$ class-switched memory, NCSM = non class-switched memory, DN = double negative, $\mathrm{Breg}=$ regulatory $\mathrm{B}$ cell.

\begin{tabular}{|c|c|c|c|c|}
\hline $\begin{array}{l}\text { Immune cell } \\
\text { subtype }\end{array}$ & Effect of DMF treatment & Duration (m) & Study design & Reference \\
\hline \multirow[t]{3}{*}{ B cells } & \multirow[t]{2}{*}{ Number: decreased } & $\begin{array}{l}3,4,4-6,12 \\
18-26\end{array}$ & Follow-up & $\begin{array}{l}67,82,87, \\
90,95,100)\end{array}$ \\
\hline & & $\geq 6,18-26$ & Cross-sectional & $(83,84,92)$ \\
\hline & Percentage: no effect & 6,12 & Follow-up & $(79,93,95)$ \\
\hline \multirow[t]{7}{*}{ B cell subtypes } & $\begin{array}{l}\text { Number naive, memory, CSM, } \\
\text { NCSM, DN: decreased; Number } \\
\text { transitional: no effect }\end{array}$ & 3 & Follow-up & (90) \\
\hline & $\begin{array}{l}\text { Number memory: decreased; } \\
\text { Number Breg: increased }\end{array}$ & $4-6$ & Follow-up & $(100)$ \\
\hline & \multirow[t]{2}{*}{ Percentage naive: increased } & 6,12 & Follow-up & $(79,95)$ \\
\hline & & $6-30$ & Cross-sectional & (94) \\
\hline & $\begin{array}{l}\text { Percentage memory: decreased; } \\
\text { Percentage Breg: no effect }\end{array}$ & 6 & Follow-up & (93) \\
\hline & $\begin{array}{l}\text { Percentage CSM, NCSM, DN: } \\
\text { decreased }\end{array}$ & 6,12 & Follow-up & $(79,95)$ \\
\hline & $\begin{array}{l}\text { Percentage CSM, DN, CD80 } \\
\text { NCSM: decreased; Percentage } \\
\text { NCSM, CD } 80^{+} \text {CSM, IgM, IgG, } \\
\text { IgA: no effect }\end{array}$ & $6-30$ & Cross-sectional & (94) \\
\hline
\end{tabular}




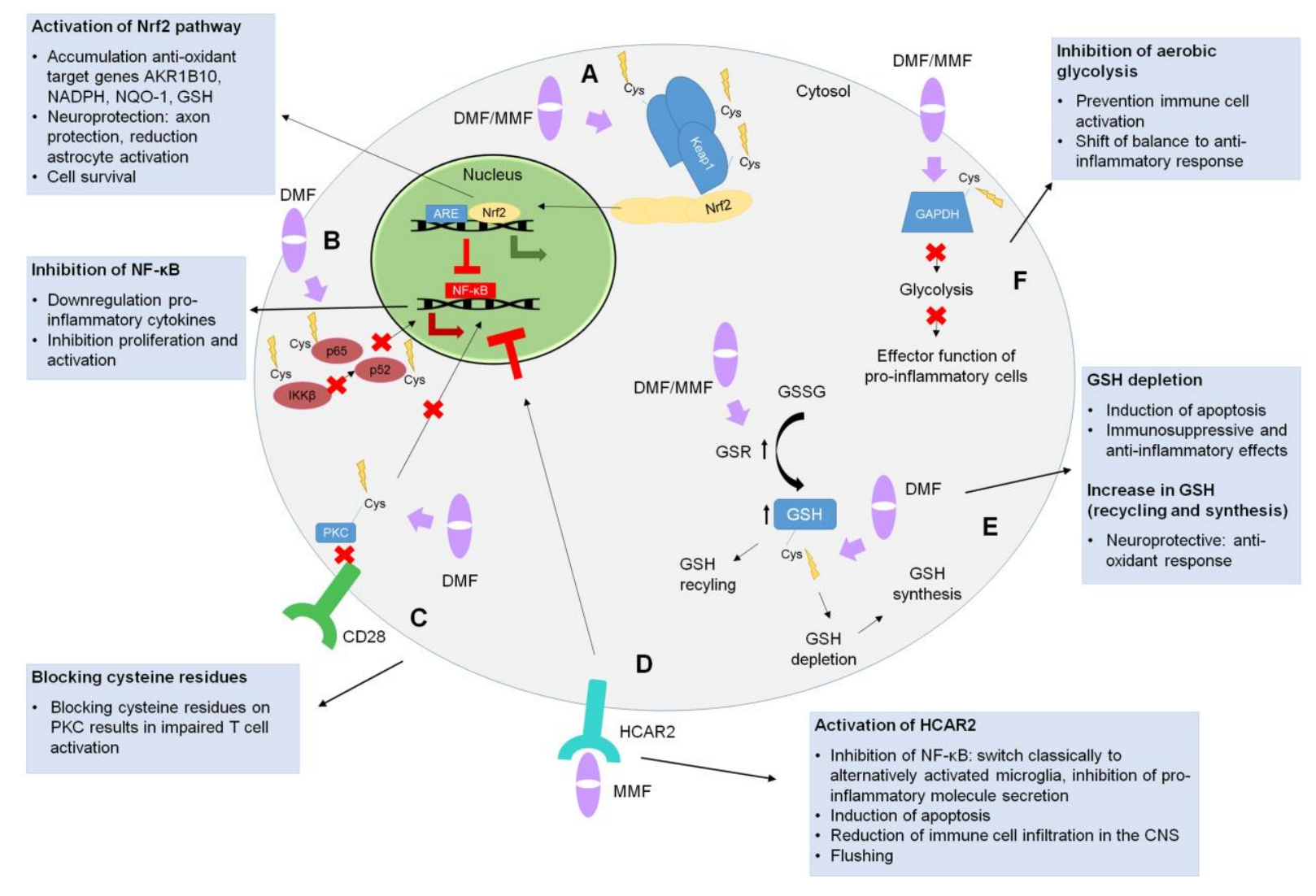

Figure 1. Molecular pathways of DMF treatment. (A) DMF and MMF react with cysteine residues of Keap1, which causes Keap1 to dissociate from Nrf2 leading to the nuclear translocation of Nrf2. Nrf2 then binds to the antioxidant response element (ARE) and drives the expression of anti-oxidant target genes, which leads to neuroprotection, reduction of astrocyte activation and cell survival. (B) DMF modifies cysteine residues of proteins involved in the NF-KB pathway (IKK $\beta$, p65, p52), which leads to the inhibition of p65 and p52 translocation. Inhibition of NF-KB then leads to inhibition of pro-inflammatory cytokine production and inhibition of cell activation and proliferation. (C) In T cells, DMF modifies cysteine residues of PKC- $\theta$ resulting in impaired activation of T cells and interruption of NF-KB activation. (D) MMF is a potent agonist of HCAR2, which results in reduced migration and infiltration of immune cells in the CNS. HCAR2 inhibits the NF-KB pathway, which results in a switch of classically activated pro-inflammatory microglia to alternatively activated microglia and the inhibition of pro-inflammatory molecule production. The binding of MMF to HCAR2 also results in the induction of apoptosis and causes flushing in MS patients. (E) DMF induces a transient GSH depletion by interacting with cysteine residues of GSH and subsequently forming DMF-GSH conjugates, which leads to apoptosis induction, immunosuppressive and anti-inflammatory effects. GSH depletion induces GSH synthesis directly, but DMF and MMF also induce GSH synthesis indirectly via GSH recycling by increasing the enzyme GSR which converts GSSG into GSH. An increase in GSH exerts a neuroprotective effect by inducing an antioxidant response. (F) DMF and MMF inhibit aerobic glycolysis in immune cells by modifying cysteine residues of GAPDH, which results in inhibition of immune cell activation and a shift from a pro-inflammatory to an antiinflammatory response. $\mathrm{DMF}=$ dimethyl fumarate, $\mathrm{MMF}=$ monomethyl fumarate, $\mathrm{Keap} 1=\mathrm{Kelch}$-like $\mathrm{ECH}$ associated protein 1, Nrf2 = nuclear factor (erythroid-derived 2)-like 2, ARE = antioxidant response element, AKR1B10 = aldo-keto reductase family 1 member B10, $\mathrm{NADPH}=$ nicotinamide adenine dinucleotide fosfaat, NQO-1 = NAD(P)H dehydrogenase (quinone 1), GSH = glutathione, IKK $\beta=1 \mathrm{~KB}$ kinase $\beta, \mathrm{NF}-\mathrm{KB}=$ nuclear factor $\mathrm{KB}, \mathrm{HCAR2}=$ hydroxycarboxylic acid receptor $2, \mathrm{PKC}-\theta=$ protein kinase $\mathrm{C}$-theta, GAPDH = glyceraldehyde-3phosphate dehydrogenase, GSR = glutathione reductase, GSSG = glutathione disulfide. 


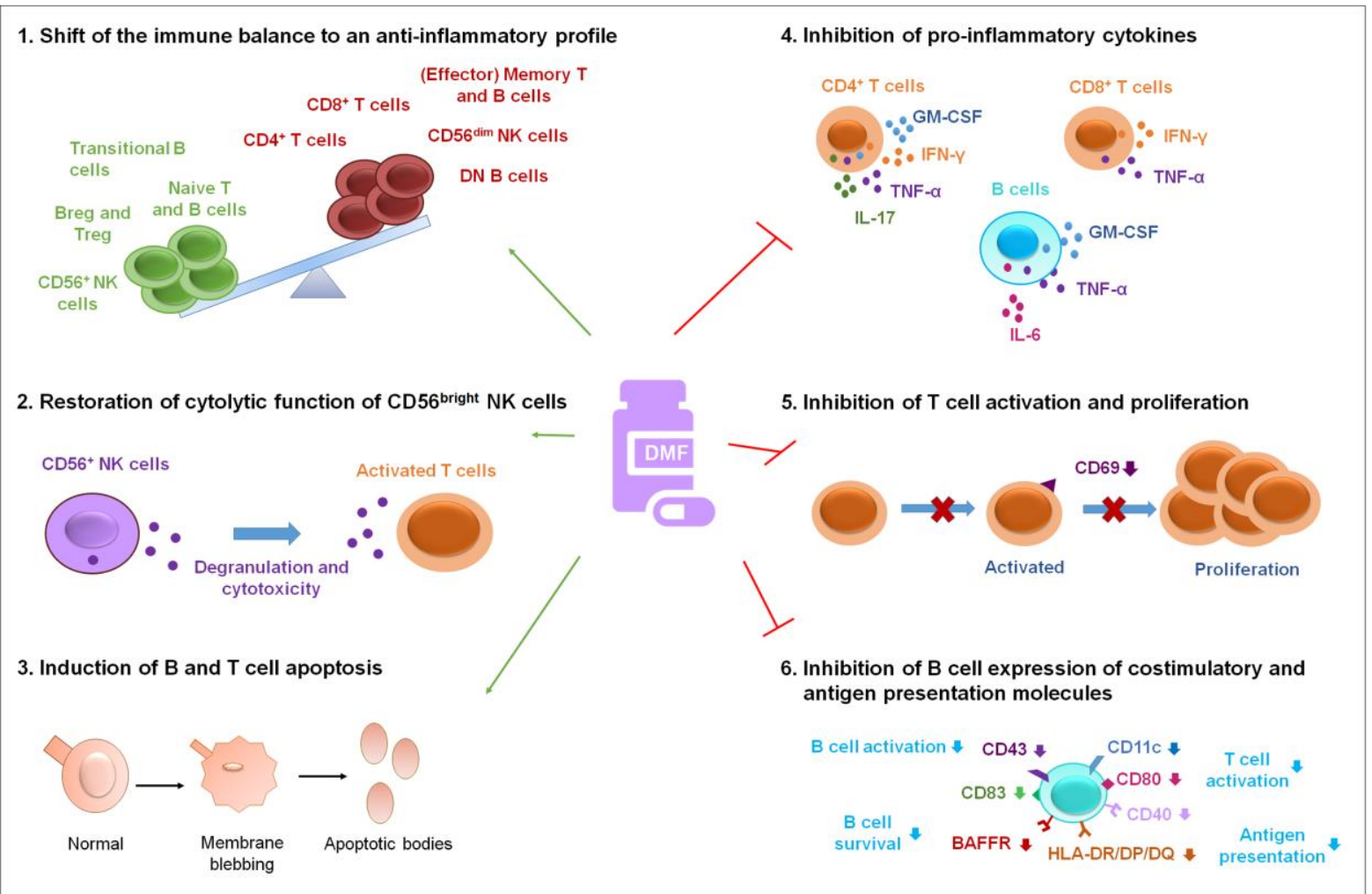

Figure 2. Effects of DMF treatment on immune cells of MS patients. (1) DMF treatment shifts the immune balance of MS patients from a pro-inflammatory ( $C D 4^{+} \mathrm{T}$ cells, $\mathrm{CD} 8^{+} \mathrm{T}$ cells, effector memory $\mathrm{T}$ and $\mathrm{B}$ cells, DN B cells, CD56 ${ }^{\text {dim }}$ NK cells) to an anti-inflammatory profile (naive T and B cells, Breg and Treg, CD56 ${ }^{\text {bright }}$ NK cells, transitional B cells). (2) DMF treatment restores the cytolytic function of CD56 bright $N K$ cells towards activated T cells, which results in increased degranulation and cytotoxicity. (3) DMF treatment induces apoptosis of T and B cells. (4) DMF treatment inhibits the expression of pro-inflammatory cytokines by CD4 ${ }^{+} \mathrm{T}$ cells (GM-CSF, IFN- $\gamma$, TNF- $\alpha$, IL-17), CD8 ${ }^{+}$T cells (IFN- $\gamma$, TNF- $\alpha$ ) and B cells (GM-CSF, TNF- $\alpha$, IL-6). (5) DMF treatment inhibits T cell activation by reducing CD69 expression and inhibits $T$ cell proliferation. (6) DMF inhibits $B$ cell expression of surface markers important for B cell - T cell interaction (CD11c, CD43, CD80, CD83), of costimulatory molecule CD40, of antigen presentation molecule HLA-DR/DP/DQ and of survival marker BAFFR. DMF = dimethyl fumarate, GM-CSF = granulocyte-macrophage colony-stimulating factor, IFN- $\nu=$ interferon $-\nu$, TNF- $\alpha=$ tumor necrosis factor alpha, BAFFR = B-cell activating factor receptor. 


\section{References}

1. Compston A, Coles A. Multiple sclerosis. Lancet (London, England). 2008;372(9648):1502-17.

2. Browne P, Chandraratna D, Angood C, Tremlett H, Baker C, Taylor BV, et al. Atlas of Multiple Sclerosis 2013: A growing global problem with widespread inequity. Neurology. 2014;83(11):1022-4.

3. Doshi A, Chataway J. Multiple sclerosis, a treatable disease. Clinical medicine (London, England). 2016;16(Suppl 6):s53-s9.

4. Wakerley B NR, Malik O. Multiple sclerosis. Medicine. 2008(36(12)):625-9.

5. Dargahi N, Katsara M, Tselios T, Androutsou ME, de Courten M, Matsoukas J, et al. Multiple Sclerosis: Immunopathology and Treatment Update. Brain sciences. 2017;7(7).

6. Legroux L, Arbour N. Multiple Sclerosis and T Lymphocytes: An Entangled Story. Journal of neuroimmune pharmacology : the official journal of the Society on Neurolmmune Pharmacology. 2015;10(4):528-46.

7. Chastain EM, Miller SD. Molecular mimicry as an inducing trigger for CNS autoimmune demyelinating disease. Immunological reviews. 2012;245(1):227-38.

8. Fujinami RS, von Herrath MG, Christen U, Whitton JL. Molecular mimicry, bystander activation, or viral persistence: infections and autoimmune disease. Clinical microbiology reviews. 2006;19(1):80-94.

9. Hemmer B, Kerschensteiner M, Korn T. Role of the innate and adaptive immune responses in the course of multiple sclerosis. The Lancet Neurology. 2015;14(4):406-19.

10. Dendrou CA, Fugger L, Friese MA. Immunopathology of multiple sclerosis. Nature reviews Immunology. 2015;15(9):545-58.

11. Dittel BN. CD4 T cells: Balancing the coming and going of autoimmune-mediated inflammation in the CNS. Brain, behavior, and immunity. 2008;22(4):421-30.

12. Korn T, Bettelli E, Oukka M, Kuchroo VK. IL-17 and Th17 Cells. Annual review of immunology. 2009;27:485-517.

13. Neumann H, Medana IM, Bauer J, Lassmann H. Cytotoxic T lymphocytes in autoimmune and degenerative CNS diseases. Trends in neurosciences. 2002;25(6):313-9.

14. Hauser SL, Waubant E, Arnold DL, Vollmer T, Antel J, Fox RJ, et al. B-cell depletion with rituximab in relapsing-remitting multiple sclerosis. The New England journal of medicine. 2008;358(7):67688.

15. Claes N, Fraussen J, Stinissen P, Hupperts R, Somers V. B Cells Are Multifunctional Players in Multiple Sclerosis Pathogenesis: Insights from Therapeutic Interventions. Frontiers in immunology. 2015;6:642.

16. Niino $M$, Hirotani $M$, Miyazaki $Y$, Sasaki $H$. Memory and naive B-cell subsets in patients with multiple sclerosis. Neuroscience letters. 2009;464(1):74-8.

17. Fraussen J, Claes N, Van Wijmeersch B, van Horssen J, Stinissen P, Hupperts R, et al. B cells of multiple sclerosis patients induce autoreactive proinflammatory $\mathrm{T}$ cell responses. Clinical immunology (Orlando, Fla). 2016;173:124-32.

18. Claes N, Fraussen J, Vanheusden M, Hellings N, Stinissen P, Van Wijmeersch B, et al. AgeAssociated B Cells with Proinflammatory Characteristics Are Expanded in a Proportion of Multiple Sclerosis Patients. Journal of immunology (Baltimore, Md : 1950). 2016;197(12):457683.

19. Cooper MA, Fehniger TA, Turner SC, Chen KS, Ghaheri BA, Ghayur T, et al. Human natural killer cells: a unique innate immunoregulatory role for the CD56(bright) subset. Blood. 2001;97(10):3146-51.

20. Laroni A, Armentani E, Kerlero de Rosbo N, Ivaldi F, Marcenaro E, Sivori S, et al. Dysregulation of regulatory CD56(bright) NK cells/T cells interactions in multiple sclerosis. Journal of autoimmunity. 2016;72:8-18. 
21. Kastrukoff LF, Lau A, Wee R, Zecchini D, White R, Paty DW. Clinical relapses of multiple sclerosis are associated with 'novel' valleys in natural killer cell functional activity. Journal of neuroimmunology. 2003;145(1-2):103-14.

22. Kasper LH, Haque, A. \& Haque, S. Regulatory mechanims of the immune system in multiple sclerosis. T regulatory cells: turned on to turn off. J Neurol. 2007(254(Suppl 1)):I10.

23. Knippenberg S, Peelen E, Smolders J, Thewissen M, Menheere P, Cohen Tervaert JW, et al. Reduction in IL-10 producing B cells (Breg) in multiple sclerosis is accompanied by a reduced naive/memory Breg ratio during a relapse but not in remission. Journal of neuroimmunology. 2011;239(1-2):80-6.

24. Viglietta V, Baecher-Allan C, Weiner HL, Hafler DA. Loss of functional suppression by CD4+CD25+ regulatory $\mathrm{T}$ cells in patients with multiple sclerosis. The Journal of experimental medicine. 2004;199(7):971-9.

25. Gross CC, Schulte-Mecklenbeck A, Klinsing S, Posevitz-Fejfar A, Wiendl H, Klotz L. Dimethyl fumarate treatment alters circulating $T$ helper cell subsets in multiple sclerosis. Neurology(R) neuroimmunology \& neuroinflammation. 2016;3(1):e183.

26. Linker RA, Lee DH, Ryan S, van Dam AM, Conrad R, Bista P, et al. Fumaric acid esters exert neuroprotective effects in neuroinflammation via activation of the Nrf2 antioxidant pathway. Brain : a journal of neurology. 2011;134(Pt 3):678-92.

27. Mrowietz U, Altmeyer P, Bieber T, Rocken M, Schopf RE, Sterry W. Treatment of psoriasis with fumaric acid esters (Fumaderm). Journal der Deutschen Dermatologischen Gesellschaft $=$ Journal of the German Society of Dermatology : JDDG. 2007;5(8):716-7.

28. Mrowietz U, Christophers E, Altmeyer P. Treatment of psoriasis with fumaric acid esters: results of a prospective multicentre study. German Multicentre Study. The British journal of dermatology. 1998;138(3):456-60.

29. Prinz JC. The role of T cells in psoriasis. Journal of the European Academy of Dermatology and Venereology : JEADV. 2003;17(3):257-70.

30. Schweckendiek W. [Treatment of psoriasis vulgaris]. Medizinische Monatsschrift. 1959;13(2):103-4.

31. Bovenschen HJ, Langewouters AM, van de Kerkhof PC. Dimethylfumarate for psoriasis: Pronounced effects on lesional T-cell subsets, epidermal proliferation and differentiation, but not on natural killer $\mathrm{T}$ cells in immunohistochemical study. American journal of clinical dermatology. 2010;11(5):343-50.

32. Ockenfels HM, Schultewolter T, Ockenfels G, Funk R, Goos M. The antipsoriatic agent dimethylfumarate immunomodulates T-cell cytokine secretion and inhibits cytokines of the psoriatic cytokine network. The British journal of dermatology. 1998;139(3):390-5.

33. Reich $K$, Thaci D, Mrowietz U, Kamps A, Neureither M, Luger T. Efficacy and safety of fumaric acid esters in the long-term treatment of psoriasis--a retrospective study (FUTURE). Journal der Deutschen Dermatologischen Gesellschaft = Journal of the German Society of Dermatology : JDDG. 2009;7(7):603-11.

34. Schimrigk S, Brune N, Hellwig K, Lukas C, Bellenberg B, Rieks M, et al. Oral fumaric acid esters for the treatment of active multiple sclerosis: an open-label, baseline-controlled pilot study. European journal of neurology. 2006;13(6):604-10.

35. Litjens $\mathrm{NH}$, van Strijen E, van Gulpen C, Mattie H, van Dissel JT, Thio HB, et al. In vitro pharmacokinetics of anti-psoriatic fumaric acid esters. BMC pharmacology. 2004;4:22.

36. Litjens NH, Burggraaf J, van Strijen E, van Gulpen C, Mattie H, Schoemaker RC, et al. Pharmacokinetics of oral fumarates in healthy subjects. British journal of clinical pharmacology. 2004;58(4):429-32.

37. Rostami-Yazdi M, Clement B, Mrowietz U. Pharmacokinetics of anti-psoriatic fumaric acid esters in psoriasis patients. Archives of Dermatological Research. 2010;302(7):531-8.

38. Rostami-Yazdi M, Clement B, Schmidt TJ, Schinor D, Mrowietz U. Detection of metabolites of fumaric acid esters in human urine: implications for their mode of action. The Journal of investigative dermatology. 2009;129(1):231-4. 
39. Schmidt TJ, Ak M, Mrowietz U. Reactivity of dimethyl fumarate and methylhydrogen fumarate towards glutathione and $\mathrm{N}$-acetyl-L-cysteine--preparation of S-substituted thiosuccinic acid esters. Bioorganic \& medicinal chemistry. 2007;15(1):333-42.

40. Ghashghaeinia M, Bobbala D, Wieder T, Koka S, Bruck J, Fehrenbacher B, et al. Targeting glutathione by dimethylfumarate protects against experimental malaria by enhancing erythrocyte cell membrane scrambling. American journal of physiology Cell physiology. 2010;299(4):C791-804.

41. Sheikh SI, Nestorov I, Russell H, O'Gorman J, Huang R, Milne GL, et al. Tolerability and pharmacokinetics of delayed-release dimethyl fumarate administered with and without aspirin in healthy volunteers. Clinical therapeutics. 2013;35(10):1582-94.e9.

42. Gillard GO, Collette B, Anderson J, Chao J, Scannevin RH, Huss DJ, et al. DMF, but not other fumarates, inhibits NF-kappaB activity in vitro in an Nrf2-independent manner. Journal of neuroimmunology. 2015;283:74-85.

43. Moi P, Chan K, Asunis I, Cao A, Kan YW. Isolation of NF-E2-related factor 2 (Nrf2), a NF-E2-like basic leucine zipper transcriptional activator that binds to the tandem NF-E2/AP1 repeat of the beta-globin locus control region. Proceedings of the National Academy of Sciences of the United States of America. 1994;91(21):9926-30.

44. Battino M, Giampieri F, Pistollato F, Sureda A, de Oliveira MR, Pittala V, et al. Nrf2 as regulator of innate immunity: A molecular Swiss army knife! Biotechnology advances. 2018;36(2):358-70.

45. Benarroch EE. Nrf2, cellular redox regulation, and neurologic implications. Neurology. 2017;88(20):1942-50.

46. Brennan MS, Matos MF, Li B, Hronowski X, Gao B, Juhasz P, et al. Dimethyl fumarate and monoethyl fumarate exhibit differential effects on KEAP1, NRF2 activation, and glutathione depletion in vitro. PloS one. 2015;10(3):e0120254.

47. Kihara Y, Groves A, Rivera RR, Chun J. Dimethyl fumarate inhibits integrin alpha4 expression in multiple sclerosis models. Annals of clinical and translational neurology. 2015;2(10):978-83.

48. Schulze-Topphoff U, Varrin-Doyer M, Pekarek K, Spencer CM, Shetty A, Sagan SA, et al. Dimethyl fumarate treatment induces adaptive and innate immune modulation independent of Nrf2. Proceedings of the National Academy of Sciences of the United States of America. 2016;113(17):4777-82.

49. Blewett MM, Xie J, Zaro BW, Backus KM, Altman A, Teijaro JR, et al. Chemical proteomic map of dimethyl fumarate-sensitive cysteines in primary human $T$ cells. Science signaling. 2016;9(445):rs10.

50. Gerdes S, Shakery K, Mrowietz U. Dimethylfumarate inhibits nuclear binding of nuclear factor kappaB but not of nuclear factor of activated T cells and CCAAT/enhancer binding protein beta in activated human T cells. The British journal of dermatology. 2007;156(5):838-42.

51. Chen H, Assmann JC, Krenz A, Rahman M, Grimm M, Karsten CM, et al. Hydroxycarboxylic acid receptor 2 mediates dimethyl fumarate's protective effect in EAE. The Journal of clinical investigation. 2014;124(5):2188-92.

52. Benyo Z, Gille A, Kero J, Csiky M, Suchankova MC, Nusing RM, et al. GPR109A (PUMA-G/HM74A) mediates nicotinic acid-induced flushing. The Journal of clinical investigation. 2005;115(12):3634-40.

53. Kostylina G, Simon D, Fey MF, Yousefi S, Simon HU. Neutrophil apoptosis mediated by nicotinic acid receptors (GPR109A). Cell death and differentiation. 2008;15(1):134-42.

54. Maciejewski-Lenoir D, Richman JG, Hakak Y, Gaidarov I, Behan DP, Connolly DT. Langerhans cells release prostaglandin $\mathrm{D} 2$ in response to nicotinic acid. The Journal of investigative dermatology. 2006;126(12):2637-46.

55. Offermanns S. Hydroxy-Carboxylic Acid Receptor Actions in Metabolism. Trends in endocrinology and metabolism: TEM. 2017;28(3):227-36.

56. Offermanns S, Schwaninger M. Nutritional or pharmacological activation of HCA(2) ameliorates neuroinflammation. Trends in molecular medicine. 2015;21(4):245-55. 
57. Rahman $M$, Muhammad S, Khan MA, Chen $H$, Ridder DA, Muller-Fielitz $H$, et al. The betahydroxybutyrate receptor HCA2 activates a neuroprotective subset of macrophages. Nature communications. 2014;5:3944.

58. Parodi B, Rossi S, Morando S, Cordano C, Bragoni A, Motta C, et al. Fumarates modulate microglia activation through a novel HCAR2 signaling pathway and rescue synaptic dysregulation in inflamed CNS. Acta neuropathologica. 2015;130(2):279-95.

59. Digby JE, Martinez F, Jefferson A, Ruparelia N, Chai J, Wamil M, et al. Anti-inflammatory effects of nicotinic acid in human monocytes are mediated by GPR109A dependent mechanisms. Arteriosclerosis, thrombosis, and vascular biology. 2012;32(3):669-76.

60. Zandi-Nejad K, Takakura A, Jurewicz M, Chandraker AK, Offermanns S, Mount D, et al. The role of HCA2 (GPR109A) in regulating macrophage function. FASEB journal : official publication of the Federation of American Societies for Experimental Biology. 2013;27(11):4366-74.

61. Gold R, Kappos L, Arnold DL, Bar-Or A, Giovannoni G, Selmaj K, et al. Placebo-controlled phase 3 study of oral BG-12 for relapsing multiple sclerosis. The New England journal of medicine. 2012;367(12):1098-107.

62. Lu SC. Glutathione synthesis. Biochimica et biophysica acta. 2013;1830(5):3143-53.

63. Dibbert S, Clement B, Skak-Nielsen T, Mrowietz U, Rostami-Yazdi M. Detection of fumarateglutathione adducts in the portal vein blood of rats: evidence for rapid dimethylfumarate metabolism. Arch Dermatol Res. 2013;305(5):447-51.

64. Lehmann JC, Listopad JJ, Rentzsch CU, Igney FH, von Bonin A, Hennekes $\mathrm{HH}$, et al. Dimethylfumarate induces immunosuppression via glutathione depletion and subsequent induction of heme oxygenase 1. The Journal of investigative dermatology. 2007;127(4):835-45.

65. Albrecht P, Bouchachia I, Goebels N, Henke N, Hofstetter HH, Issberner A, et al. Effects of dimethyl fumarate on neuroprotection and immunomodulation. Journal of neuroinflammation. 2012;9:163.

66. Huang H, Taraboletti A, Shriver LP. Dimethyl fumarate modulates antioxidant and lipid metabolism in oligodendrocytes. Redox biology. 2015;5:169-75.

67. Diebold M, Sievers C, Bantug G, Sanderson N, Kappos L, Kuhle J, et al. Dimethyl fumarate influences innate and adaptive immunity in multiple sclerosis. Journal of autoimmunity. 2018;86:39-50.

68. Kornberg MD, Bhargava P, Kim PM, Putluri V, Snowman AM, Putluri N, et al. Dimethyl fumarate targets GAPDH and aerobic glycolysis to modulate immunity. Science (New York, NY). 2018;360(6387):449-53.

69. Shi LZ, Wang R, Huang G, Vogel P, Neale G, Green DR, et al. HIF1alpha-dependent glycolytic pathway orchestrates a metabolic checkpoint for the differentiation of TH17 and Treg cells. The Journal of experimental medicine. 2011;208(7):1367-76.

70. Vats D, Mukundan L, Odegaard JI, Zhang L, Smith KL, Morel CR, et al. Oxidative metabolism and PGC-1beta attenuate macrophage-mediated inflammation. Cell metabolism. 2006;4(1):13-24.

71. Schilling S, Goelz S, Linker R, Luehder F, Gold R. Fumaric acid esters are effective in chronic experimental autoimmune encephalomyelitis and suppress macrophage infiltration. Clinical and experimental immunology. 2006;145(1):101-7.

72. Demir S, Heckers S, Pedreiturria X, Hess D, Trampe AK, Chan A, et al. Low dose fumaric acid esters are effective in a mouse model of spontaneous chronic encephalomyelitis. Journal of neuroimmunology. 2015;285:16-21.

73. Reick C, Ellrichmann G, Thone J, Scannevin RH, Saft C, Linker RA, et al. Neuroprotective dimethyl fumarate synergizes with immunomodulatory interferon beta to provide enhanced axon protection in autoimmune neuroinflammation. Experimental neurology. 2014;257:50-6.

74. Biogen. History accessed 14 june 2018 [Available from: https://www.biogen.com/en us/historyoverview.html.

75. Kappos L, Gold R, Miller DH, Macmanus DG, Havrdova E, Limmroth V, et al. Efficacy and safety of oral fumarate in patients with relapsing-remitting multiple sclerosis: a multicentre, randomised, 
double-blind, placebo-controlled phase $\mathrm{Ilb}$ study. Lancet (London, England). 2008;372(9648):1463-72.

76. Fox RJ, Miller DH, Phillips JT, Hutchinson M, Havrdova E, Kita M, et al. Placebo-controlled phase 3 study of oral BG-12 or glatiramer in multiple sclerosis. The New England journal of medicine. 2012;367(12):1087-97.

77. Gold R, Giovannoni G, Phillips JT, Fox RJ, Zhang A, Meltzer L, et al. Efficacy and safety of delayedrelease dimethyl fumarate in patients newly diagnosed with relapsing-remitting multiple sclerosis (RRMS). Multiple sclerosis (Houndmills, Basingstoke, England). 2015;21(1):57-66.

78. Giovannoni G, Gold R, Kappos L, Arnold DL, Bar-Or A, Marantz JL, et al. Delayed-release dimethyl fumarate and disability assessed by the Multiple Sclerosis Functional Composite: Integrated analysis of DEFINE and CONFIRM. Multiple sclerosis journal - experimental, translational and clinical. 2016;2:2055217316634111.

79. Montes Diaz G, Fraussen J, Van Wijmeersch B, Hupperts R, Somers V. Dimethyl fumarate induces a persistent change in the composition of the innate and adaptive immune system in multiple sclerosis patients. Scientific reports. 2018;8(1):8194.

80. Gold R, Arnold DL, Bar-Or A, Hutchinson M, Kappos L, Havrdova E, et al. Long-term effects of delayed-release dimethyl fumarate in multiple sclerosis: Interim analysis of ENDORSE, a randomized extension study. Multiple sclerosis (Houndmills, Basingstoke, England). 2017;23(2):253-65.

81. Baharnoori M, Lyons J, Dastagir A, Koralnik I, Stankiewicz JM. Nonfatal PML in a patient with multiple sclerosis treated with dimethyl fumarate. Neurology(R) neuroimmunology \& neuroinflammation. 2016;3(5):e274.

82. Spencer CM, Crabtree-Hartman EC, Lehmann-Horn K, Cree BA, Zamvil SS. Reduction of CD8(+) T lymphocytes in multiple sclerosis patients treated with dimethyl fumarate. Neurology(R) neuroimmunology \& neuroinflammation. 2015;2(3):e76.

83. Wu Q, Wang Q, Mao G, Dowling CA, Lundy SK, Mao-Draayer Y. Dimethyl Fumarate Selectively Reduces Memory T Cells and Shifts the Balance between Th1/Th17 and Th2 in Multiple Sclerosis Patients. Journal of immunology (Baltimore, Md : 1950). 2017;198(8):3069-80.

84. Fleischer $V$, Friedrich $M$, Rezk A, Buhler $U$, Witsch $E$, Uphaus $T$, et al. Treatment response to dimethyl fumarate is characterized by disproportionate CD8+ T cell reduction in MS. Multiple sclerosis (Houndmills, Basingstoke, England). 2018;24(5):632-41.

85. Chaves C, Ganguly R, Ceresia C, Camac A. Lymphocyte subtypes in relapsing-remitting multiple sclerosis patients treated with dimethyl fumarate. Multiple sclerosis journal - experimental, translational and clinical. 2017;3(2):2055217317702933.

86. Fox RJ, Chan A, Gold R, Phillips JT, Selmaj K, Chang I, et al. Characterizing absolute lymphocyte count profiles in dimethyl fumarate-treated patients with MS: Patient management considerations. Neurology Clinical practice. 2016;6(3):220-9.

87. Berkovich R, Weiner LP. Effects of dimethyl fumarate on lymphocyte subsets. Multiple sclerosis and related disorders. 2015;4(4):339-41.

88. Khatri BO, Garland J, Berger J, Kramer J, Sershon L, Olapo T, et al. The effect of dimethyl fumarate (Tecfidera) on lymphocyte counts: A potential contributor to progressive multifocal leukoencephalopathy risk. Multiple sclerosis and related disorders. 2015;4(4):377-9.

89. Hoxtermann S, Nuchel C, Altmeyer P. Fumaric acid esters suppress peripheral CD4- and CD8positive lymphocytes in psoriasis. Dermatology (Basel, Switzerland). 1998;196(2):223-30.

90. Li R, Rezk A, Ghadiri M, Luessi F, Zipp F, Li H, et al. Dimethyl Fumarate Treatment Mediates an Anti-Inflammatory Shift in B Cell Subsets of Patients with Multiple Sclerosis. Journal of immunology (Baltimore, Md : 1950). 2017;198(2):691-8.

91. Ghadiri M, Rezk A, Li R, Evans A, Luessi F, Zipp F, et al. Dimethyl fumarate-induced lymphopenia in MS due to differential T-cell subset apoptosis. Neurology $(R)$ neuroimmunology \& neuroinflammation. 2017;4(3):e340. 
92. Longbrake EE, Ramsbottom MJ, Cantoni C, Ghezzi L, Cross AH, Piccio L. Dimethyl fumarate selectively reduces memory $T$ cells in multiple sclerosis patients. Multiple sclerosis (Houndmills, Basingstoke, England). 2016;22(8):1061-70.

93. Medina S, Villarrubia N, Sainz de la Maza S, Lifante J, Costa-Frossard L, Roldan E, et al. Optimal response to dimethyl fumarate associates in MS with a shift from an inflammatory to a tolerogenic blood cell profile. Multiple sclerosis (Houndmills, Basingstoke, England). 2017:1352458517717088.

94. Longbrake EE, Cantoni C, Chahin S, Cignarella F, Cross AH, Piccio L. Dimethyl fumarate induces changes in $\mathrm{B}$ - and T-lymphocyte function independent of the effects on absolute lymphocyte count. Multiple sclerosis (Houndmills, Basingstoke, England). 2018;24(6):728-38.

95. Smith MD, Martin KA, Calabresi PA, Bhargava P. Dimethyl fumarate alters B-cell memory and cytokine production in MS patients. Annals of clinical and translational neurology. 2017;4(5):351-5.

96. Cretney E, Leung PS, Trezise S, Newman DM, Rankin LC, Teh CE, et al. Characterization of Blimp1 function in effector regulatory T cells. Journal of autoimmunity. 2018.

97. Grzanka J, Leveson-Gower D, Golab K, Wang XJ, Marek-Trzonkowska N, Krzystyniak A, et al. FoxP3, Helios, and SATB1: roles and relationships in regulatory $\mathrm{T}$ cells. International immunopharmacology. 2013;16(3):343-7.

98. Peres RS, Donate PB, Talbot J, Cecilio NT, Lobo PR, Machado CC, et al. TGF-beta signalling defect is linked to low CD39 expression on regulatory $T$ cells and methotrexate resistance in rheumatoid arthritis. Journal of autoimmunity. 2018;90:49-58.

99. Rissiek A, Baumann I, Cuapio A, Mautner A, Kolster M, Arck PC, et al. The expression of CD39 on regulatory $T$ cells is genetically driven and further upregulated at sites of inflammation. Journal of autoimmunity. 2015;58:12-20.

100. Lundy SK, Wu Q, Wang Q, Dowling CA, Taitano SH, Mao G, et al. Dimethyl fumarate treatment of relapsing-remitting multiple sclerosis influences B-cell subsets. Neurology $(\mathrm{R})$ neuroimmunology \& neuroinflammation. 2016;3(2):e211.

101. Flores-Borja F, Bosma A, Ng D, Reddy V, Ehrenstein MR, Isenberg DA, et al. CD19+CD24hiCD38hi $B$ cells maintain regulatory $T$ cells while limiting $T H 1$ and $T H 17$ differentiation. Science translational medicine. 2013;5(173):173ra23.

102. Smith MD, Calabresi PA, Bhargava P. Dimethyl fumarate treatment alters NK cell function in multiple sclerosis. European journal of immunology. 2018;48(2):380-3.

103. Bielekova B, Catalfamo M, Reichert-Scrivner S, Packer A, Cerna M, Waldmann TA, et al. Regulatory CD56(bright) natural killer cells mediate immunomodulatory effects of IL-2Ralphatargeted therapy (daclizumab) in multiple sclerosis. Proceedings of the National Academy of Sciences of the United States of America. 2006;103(15):5941-6.

104. Gross CC, Schulte-Mecklenbeck A, Runzi A, Kuhlmann T, Posevitz-Fejfar A, Schwab N, et al. Impaired NK-mediated regulation of T-cell activity in multiple sclerosis is reconstituted by IL-2 receptor modulation. Proceedings of the National Academy of Sciences of the United States of America. 2016;113(21):E2973-82.

105. Jiang W, Chai NR, Maric D, Bielekova B. Unexpected role for granzyme K in CD56bright NK cellmediated immunoregulation of multiple sclerosis. Journal of immunology (Baltimore, Md : 1950). 2011;187(2):781-90.

106. Maghazachi AA, Sand KL, Al-Jaderi Z. Glatiramer Acetate, Dimethyl Fumarate, and Monomethyl Fumarate Upregulate the Expression of CCR10 on the Surface of Natural Killer Cells and Enhance Their Chemotaxis and Cytotoxicity. Frontiers in immunology. 2016;7:437.

107. Vego H, Sand KL, Hoglund RA, Fallang LE, Gundersen G, Holmoy T, et al. Monomethyl fumarate augments NK cell lysis of tumor cells through degranulation and the upregulation of NKp46 and CD107a. Cellular \& molecular immunology. 2016;13(1):57-64.

108. Treumer F, Zhu K, Glaser R, Mrowietz U. Dimethylfumarate is a potent inducer of apoptosis in human T cells. The Journal of investigative dermatology. 2003;121(6):1383-8. 
109. Schneider A, Long SA, Cerosaletti K, Ni CT, Samuels P, Kita M, et al. In active relapsing-remitting multiple sclerosis, effector $\mathrm{T}$ cell resistance to adaptive $\mathrm{T}$ (regs) involves IL-6-mediated signaling. Science translational medicine. 2013;5(170):170ra15.

110. Schloder J, Berges C, Luessi F, Jonuleit H. Dimethyl Fumarate Therapy Significantly Improves the Responsiveness of T Cells in Multiple Sclerosis Patients for Immunoregulation by Regulatory $\mathrm{T}$ Cells. International journal of molecular sciences. 2017;18(2). 